6. Про Стратегію реформування судоустрою, судочинства та суміжних правових інститутів на 2015-2020 роки. Указ Президента України схвалено винесений 20.05.2015 р. // База даних «Законодавство України» / Верховна Рада України. URL: https://zakon.rada.gov.ua/ laws/show/276/2015?lang=uk/ (дата звернення: 25.09.2019).

DOI https://doi.org/10.30525/978-9934-588-92-1-33

\title{
ДОВІРЧА ВЛАСНІСТЬ ЯК СПОСІБ ЗАБЕЗПЕЧЕННЯ ВИКОНАННЯ ЗОБОВ'ЯЗАННЯ: ПЕРЕВАГИ Й НЕДОЛІКИ
}

\author{
Гелецька I. O. \\ кандидат юридичних наук, \\ заступник директора з навчальної, наукової роботи \\ та міжнародного співробітниитвва \\ Галицького коледжу імені В 'ячеслава Чорновола \\ Савошак I. М. \\ здобувач вищої освіти юридичного відділення \\ Галицького коледжу імені В'ячеслава Чорновола \\ м. Тернопіль, Украӥна
}

Зобов'язання - обов'язковий елемент будь-яких договірних відносин, адже лише вони покликані гарантувати їх нормальне функціонування. Крім того, зобов'язання повинні закріплюватись певними способами та механізмами забезпечення їх виконання.

У Цивільному кодексі України (далі - ЦК України) до 2019 року, було передбачено наступні способи забезпечення виконання зобов'язання: неустойка, завдаток, застава, порука, гарантія та притримання [1]. Проте, за останні роки мали місце декілька спроб запровадити довірчу власність як спосіб забезпечення виконання зобов'язання. Започатковано цей процес було у 2016 році, коли до розгляду було представлено проєкт Закону України «Про внесення змін до деяких законодавчих актів України щодо запровадження права довірчої власності як способу забезпечення виконання зобов'язань». Зазначений законопроєкт активно обговорювався у зв'язку 3 неоднозначністю інституту права довірчої власності в цивільному праві України. Друга спроба була більш вдалою, а відтак 20.09.2019 року було прийнято Закон України «Про внесення змін до деяких 
законодавчих актів України, щодо стимулювання інвестиційної діяльності в Україні» за № 132-IX [2]. 3 того часу главу 49 ЦК України доповнили таким способом забезпечення виконання зобов'язання як довірча власність.

За положеннями ст. $597^{1}$ ЦК України право довірчої власності $€$ різновидом права власності за яким кредитор, що отримав майно у довірчу власність, не має права самостійно відчужувати таке майно, окрім як для звернення стягнення на нього, а також його викупу для суспільних потреб у порядку, який встановлений законом. Насамперед виникає питання, чому законодавець знову, як і у ст. 316 ЦК України, ухилився від надання визначення поняттю права довірчої власності. Означена категорія розглядається ним в площині різновиду права власності без пояснення сутності цього правового інституту та лише як один із способів забезпечення виконання зобов'язань.

Безперечно, слід погодитись із позицією К.Г. Некіт щодо необхідності нормативного закріплення у ЦК України уніфікованого визначення поняття права довірчої власності, а у випадку визнання даного способу забезпечення виконання зобов'язання різновидом права власності, слід визначати й наявність у довірчого власника правомочностей володіння, користування й розпорядження майном [3, с. 18].

Відповідно до ст.ст. 316-320 ЦК України право власності характеризується такими ознаками як самостійність, безумовність, безстроковість, безмежність.

Натомість у відносинах довірчої власності довірчому власнику не передається право володарювання над майном. Більше того, його право розпорядження обмежене і проявляється лише можливістю звернення стягнення на об'єкт власності, а також викупу його для суспільних потреб у порядку, встановленому законодавством.

По-друге, має місце умова переходу такого майна у довірчу власність - невиконання довірчим засновником основного зобов'язання. 3 цього випливає і третя ознака, яка полягає у тому, що даний спосіб забезпечення має відносний характер. Також для цієї категорії характерна строковість, оскільки час ііі існування у прямій залежності від часу існування основного зобов'язання.

Відтак, основними ознаками довірчої власності як способу забезпечення виконання зобов'язання $є$ : обмеженість, строковість, умовність, відносність, що в цілому нехарактерне для права власності.

Негативним моментом означеного способу забезпечення вважається те, що боржник, навіть у випадку належного виконання свого зобов'язання несе ризик втрати майна, оскільки за положеннями ст. $597^{7}$ ЦК України обов'язковими умовами звернення стягнення на майно, якщо інше не зазначено у договорі $є$ : державна реєстрація 
рішення про припинення не лише юридичної особи - боржника, а й власника, наявність судової постанови про визнання банкрутом боржника за основним зобов'язанням чи довірчого власника або відкриття щодо них ліквідаційної процедури, а також смерті божника, визнання його недієздатним чи оголошення померлим.

На нашу думку, має місце ще одна проблемна сторона довірчої власності як способу забезпечення виконання зобов'язання. Вона полягає у тому, що дефініція ч. 4 ст. $597^{1}$ декларує обов'язок кредитора запропонувати боржнику перед наданням кредиту чи позики інший спосіб забезпечення виконання зобов'язання. Із зрозумілих причин, які наведені вище, боржник буде відмовлятися від цього способу забезпечення та обирати інший, більш вигідний для нього. Саме тому, норми передбачені у параграфі 8 глави 49 ЦК України скоріш за все не матимуть практичного застосування.

Наступним недоліком вважаємо те, що за правилами ст. $597^{9}$ ЦК України у разі прийняття рішення про звернення стягнення на житлове приміщення, яке за умовами договору визначається об'єктом довірчої власності, усі мешканці повинні протягом десяти днів звільнити його. Важливим моментом тут виступає письмова вимога власника про звільнення вказаного об'єкту. Проте, законодавством не зазначається перелік осіб, яких примусово виселяти не можна у порядку встановленому даною статтею. 3 цього можна зробити висновок, що виселеними можуть бути особи пенсійного віку, особи з інвалідністю та інші незахищені верстви населення. Варто наголосити, що відповідно до ст. 47 Конституції України кожен має право на житло [4]. Тому у даному випадку норма ЦК України порушує конституційні права особи.

Разом 3 тим, мають місце і певні переваги довірчої власності як способу забезпечення виконання зобов'язання. Так, на відміну від застави (іпотеки) у разі порушення боржником свого обов'язку 3 повернення кредиту (якщо договором про іпотеку не передбачена можливість звернути стягнення на предмет іпотеки у позасудовому порядку), довірчому власнику не потрібно звертати стягнення на майно передане в довірчу власність в судовому порядку. Він має досить можливостей для того, аби відчужити майно та повернути позичені кошти без судової тяганини шляхом продажу вказаного майна або звернення на нього стягнення іншим чином, передбаченим у договорі [5].

Також цивільне законодавство унеможливлює накладення арешту або звернення стягнення за зобов'язаннями боржника перед іншими особами щодо майна, яке об'єктом довірчої власності. Це пояснюється тим, що право власності особи, яка передала таке майно, припинилось 3 моменту встановлення довірчої власності. 
Таким чином, переваги даного способу забезпечення виконання зобов'язання існують лише для однієї сторони - кредитора.

Висновки. Зважаючи на наведене вище, слід зазначити, що право довірчої власності як спосіб забезпечення виконання зобов'язання породжує багато непорозумінь, питань та суперечок, а відтак потребує більш детального врегулювання та розгляду. Це нововведення законодавця сприймається неоднозначно у зв'язку з тим, що з одного боку покликане забезпечувати баланс між інтересами кредитора i боржника, а з іншого, суттєво обмежує права довірчого засновника.

Одним із вагомих недоліків означеного способу забезпечення виконання зобов'язання $€$ наявність суперечностей між нормами Конституції України та нормами цивільного законодавства у частині гарантування фізичній особі права на житло та наявності ризику порушення майнових прав боржника за положеннями ст. $597^{9}$ ЦК України.

Перевагами довірчої власності, як способу забезпечення виконання зобов'язання, варто вважати спрощену систему звернення стягнення на майно та правовий захист майнових інтересів кредитора.

Оскільки спільних ознак 3 інститутом власності у них у них практично не існує, вважаємо, що довірчу власність необхідно виокремити в окремий інститут цивільного права. Доречним також $\mathrm{\epsilon}$ i внесення змін до ст. $597^{7}$ ЦК України у частині захисту майнових прав боржника та до ст. $597^{9}$ цього ж кодифікованого акту, шляхом доповнення її переліком осіб, які не можуть бути примусово виселені зі своїх житлових приміщень.

\section{Література:}

1. Цивільний кодекс України: Закон України від від 16.01.2003. № 435-IV / Верховна рада України. URL: https://zakon.rada.gov.ua/laws/ show/435-15\#Text (дата звернення: 11.10.2020).

2. Про внесення змін до деяких законодавчих актів України щодо стимулювання інвестиційної діяльності в України : Закон Україні від 20.09.2019 p. № 132-IX / Верховна рада України. URL: https://zakon.rada.gov.ua/laws/show/132-20\#Text____ата звернення: 11.10.2020).

3. Некіт К. Г. Деякі проблеми запровадження права довірчої власності як способу забезпечення виконання зобов'язань. Актуальні проблеми захисту права власності : матер. кругл. столу (м. Одеса, 17 червня 2016 р.). Одеса: Фенікс, 2016. С. 17-20.

4. Конституція України: Закон України від 28 червня 1996 р. № 254к/96-ВР / Верховна рада України. Відомості Верховної Ради Украӥни. 1996. № 30. Ст. 141. 
5. Тетеря І. Право довірчої власності. Які наслідки для громадян та бізнесу. Бізнес Цензор: веб-сайт. URL:https://biz.censor.net/columns/ 3156278/pravo_dovrcho_vlasnost_yak_nasldki_dlya_gromadyan_ta_bznesu (дата звернення: 15.10.2020).

DOI https://doi.org/10.30525/978-9934-588-92-1-34

\title{
THE PHENOMENON OF RESTORATION OF THE LIMITATION PERIOD. GROUNDS AND CONSEQUENCES
}

\author{
Guyvan P. D. \\ Candidate of Juridical Sciences, Honored Lawyer of Ukraine, \\ Professor \\ Poltava Business Institute \\ Poltava, Ukraine
}

Judicial protection of the violated subjective right of a person may take place if he / she has filed a claim with the court within the statutory limitation period. In case of omission of the specified term the judicial protective property of the substantive law is repaid. At the same time, the law contains certain guarantees for subjects who missed the time of filing a claim for a good reason: if this fact is established in the process, the violated right is subject to protection. Modern law, based on the civil law principle of guaranteeing the implementation of subjective law [1, p. 105], provides for the possibility of its protection and after the coincidence of the period established for the claim. Part 5 of Article 267 of the Civil Code of Ukraine states that if the court finds valid the reasons for the omission of the statute of limitations, the violated right is subject to protection. It should be noted that the definition of «restoration of the statute of limitations» widely used in law and civilization does not quite accurately reflect the essence of this phenomenon. To be punctual, it is necessary to refer to the literal text of the relevant provision of the Central Committee of Ukraine, which deals with the exercise of the right to judicial protection outside the existence of such a right to protection. Thus, it is a question of restoration of compulsory ability of the protective substantive right, instead of the course of term. Thus such protection will take place already after the termination of existence of the substantive right to the claim owing to one-time renewal of protective legal capacity of the right [2, p. 398]. 